\title{
PENGARUH PENGGUNAAN METODE PEMBELAJARAN GAMBAR BERSERI DAN KECERDASAN SPASIAL TERHADAP KETERAMPILAN MENULIS KARANGAN DESKRIPSI
}

\author{
Piet Soumokil \\ Juliaans E.R. Marantika ${ }^{2}$ \\ Samuel. J. Litualy ${ }^{3}$
}

\begin{abstract}
Abstrak. Tujuan penelitian ini adalah 1) untuk mengetahui pengaruh metode pembelajaran terhadap keterampilan menulis karangan deskripsi; 2) untuk mengetahui pengaruh kecerdasan spasial terhadap keterampilan menulis karangan deskripsi; 3) untuk mengetahui perbedaan pengaruh antara kecerdasan spasial tinggi yang diajarkan dengan metode gambar berseri maupun konvnsional dan kecerdasan spasial rendah yang diajarkan dengan metode gambar berseri maupun konvensional terhadap keterampilan menulis karangan deskripsi. Penelitian ini dilaksanakan pada Program Studi Pendidikan Bahasa Jerman Fakultas Keguruan dan Ilmu Pendidikan Universitas Pattimura Ambon, tahun akademik 2016/2017. Metode penelitian yang digunakan adalah metode eksperimen dengan rancangan faktorial $2 \times 2$. Sampel penelitian berjumlah 18 mahasiswa yang dipilih secara acak pada setiap kelompok. Instrumen yang digunakan untuk mengumpulkan data yakni (1) tes menulis karangan deskripsi dan (2) tes DAT atau space relation untuk mengukur kecerdasan spasial. Selanjutnya teknik analisis data yang digunakan untuk membuktikan hipotesis pertama dan kedua adalah uji Mann Whitney. Sedangkan hipotesis ketiga dibuktikan dengan menggunakan uji Kruskal Wallis. Berdasarkan hasil penelitian dapat disimpulkan bahwa metode pembelajaran gambar berseri lebih baik daripada metode pembelajaran konvensional dalam meningkatkan keterampilan menulis karangan deskripsi. Selain itu, hasil keterampilan menulis karangan deskripsi pada kelompok mahasiswa yang memiliki kecerdasan tinggi tidak lebih baik daripada kelompok mahasiswa yang memiliki kecerdasan spasial rendah. Serta terdapat perbedaan pengaruh antara kecerdasan spasial tinggi yang diajarkan dengan metode gambar berseri maupun konvensional dan kecerdasan spasial rendah yang diajarkan dengan metode gambar berseri maupun konvensional terhadap keterampilan menulis karangan deskripsi.
\end{abstract}

Kata kunci: Metode Gambar Berseri, Kecerdasan Spasial, Karangan Deskripsi

\section{Pendahuluan}

Menulis merupakan suatu bentuk komunikasi dua arah yang efektif untuk mengkomunikasikan ide atau gagasan meskipun tidak bertatapan langsung dengan lawan bicara. Keterampilan menulis juga disebut sebagai salah satu keterampilan

\footnotetext{
${ }^{1}$ Dosen Program Studi Pendidikan Bahasa Jerman FKIP Universitas Pattimura

${ }^{2}$ Idem

${ }^{3}$ Idem
} 
produktif selain keterampilan berbicara. Artinya, setelah melalui proses menulis maka akan dihasilkan suatu karya tulis. Pada saat menulis seseorang membutuhkan waktu untuk mengembangkan topik yang dipilih dengan berbantuan kata-kata kunci, kemudian menyusun kata-kata kunci tersebut menjadi rangkaian kalimat atau paragraf, membaca kembali apa yang

ditulisnya, selanjutnya mempertimbangkannyaserta memperbaikinya. Agar terampil menulis dibutuhkan kemampuan berpikir secara teratur dan logis, kemampuan mengungkapkan pikiran atau gagasan secara jelas, dengan menggunakan bahasa yang tepat, dan kemampuan menerapkan kaidah tulis menulis dengan baik (Darmiyati Zuchdi dan Budiasih, 1997:62).

Dalam kaitannya dengan pembelajaran Bahasa Jerman pada Program Studi Pendidikan Bahasa Jerman Universitas Pattimura Ambon, pembelajaran menulis diberikan secara berkelanjutan sejak semester pertama hingga semester keempat pada mata kuliah Sprache I-IV. Karena penelitian ini dilaksanakan pada semester kedua sehingga peneliti hanya memfokuskan pada matakuliah Sprache II.

Dalam meningkatkan keterampilan menulis pada mata kuliah Sprache II mahasiswa diharapkan dapat menuangkan ide atau gagasan tentang tema-tema sederhana dalam kehidupan sehari-hari dengan baik dan benar, salah satunya dalam bentuk karangan deskripsi. Karangan deskripsi merupakan salah satu jenis komunikasi tertulis yang menggambarkan atau melukiskan suatu objek secara detail atau mendalam sesuai keadaan yang sebenar-benarnya tentang objek yang dilukiskan tersebut (Hartono, 2003). Oleh karena itu, dalam menulis karangan deskripsi, mahasiswa perlu terampil menggunakan kosakata, struktur kalimat, pengembangan paragraf, dan logika berbahasa (Wagiran dan Doyin, 2005).

Namun kenyataannya, mahasiswa masih mengalami kesulitan untuk mengembangkan karangan deskripsi. Kesulitan-kesulitan tersebut disebabkan oleh beberapa faktor yakni, keterbatasan kosakata, kurangnya minat dan motivasi, serta pemilihan metode dalam pembelajaran yang kurang efektif. Dan berdasarkan hasil pengamatan diketahui bahwa metode pembelajaran yang kerap digunakan yaitu ceramah atau konvensional. Penerapan metode ini menyebabkan mahasiswa kurang tertarik dan kurang termotivasi terhadap pembelajaran menulis karangan deskripsi. Mahasiswa tidak memiliki gambaran atau ide yang cukup untuk menyusun karangan deskripsi. oleh karena itu, untuk menciptakan pembelajaran yang aktif, kreatif, dan produktif, perlu digunakan metode pembelajaran yang tepat. Salah satu metode yang mampu membantu mahasiswa dalam pembelajaran bahasa jerman khususnya untuk meningkatkan keterampilan menulis yaitu metode pembelajaran gambar berseri.

Metode pembelajaran gambar berseri merupakan rangkaian gambar-gambar yang menceritakan sebuah kegiatan dan disusun secara berurutan. Metode pembelajaran gambar berseri dianggap cocok untuk diterapkan di dalam kelas, karena membantu mahasiswa berimajinasi dan selanjutnya mengurutkan suatu cerita secara kronologis berdasarkan gambar yang mereka lihat. Dalam penerapan metode pembelajaran gambar berseri pada proses pembelajaran bahasa Jerman tentu tidak terlepas dari bagaimana cara penyajian gambar, kualitas gambar yang ditampilkan, dan juga berdasarkan kemampuan mahasiswa dalam membangun persepsinya ketika gambar-gambar tersebut ditampilkan. Dari persepsi itulah, 
mahasiswa kemudian diharapkan dapat mengembangkan hasil pengamatannya kedalam bentuk karangan. Melalui gambar berseri yang pada hakekatnya memiliki variasi warna, dan bentuk visualisasi yang unik, maka akan membentuk mahasiswa agar semakin imajinatif serta kreatif dalam proses pembelajaran. Kemampuan mahasiswa dalam membangun persepsi visual sendiri berdasarkan urutan gambar-gambar tersebut disebut dengan kecerdasan spasial.

Kecerdasan spasial adalah kemampuan untuk berpikir dalam bentuk visualisasi gambar dan mempunyai daya penglihatan yang tinggi terhadap gambar tersebut. Dalam pembelajaran bahasa Jerman mahasiswa diharakan menjadi mahasiswa yang aktif dan inovatif. Terkhususnya dalam keterampilan menulis melalui penggunaan metode pembelajaran gambar berseri, mahasiswa diharapkan secara mandiri mampu mengembangkan imajinasinya daan kemudian menuangkannya dalam bentuk karangan. Aktivitas belajar yang dominan dengan penggunaan metode pembelajaran gambar berseri serta ditinjau berdasarkan tingkat kecerdasan spasial sangat efektif dalam proses pembelajaran bahasa Jerman terkhususnya dalam meningkatkan keterampilan menulis.

\section{Metode Penelitian}

Metode yang digunakan dalam penelitian ini adalah metode eksperimen dengan desain faktorial $2 \times 2$, memperhatikan adanya kemungkinan kecerdasan spasial mempengaruhi penggunaan metode pembelajaran gambar berseri maupun konvensional terhadap keterampilan menulis karangan deskripsi. Paradigma factorial design disajikan pada Tabel 1 sebagai berikut.

Tabel 1 Faktorial Design (Desain faktorial 2x2)

\begin{tabular}{|l|c|c|}
\hline Metode pembelajaran & \multirow{2}{*}{ Gambar Berseri (A1) } & Konvensional (A2) \\
\cline { 1 - 1 } Kecerdasan Visual & & A2B1 \\
\hline Tinggi (B1) & A1B1 & A2B2 \\
\hline Rendah (B2) & A1B2 & \\
\hline
\end{tabular}

Keterangan :

A1 = kelompok mahasiswa yang diajarkan dengan metode pembelajaran gambar berseri

A2 $=$ kelompok mahasiswa yang diajarkan dengan metode pembelajaran konvensional

$\mathrm{B} 1=$ kelompok mahasiswa dengan kategori kecerdasan spasial tinggi

B2 = kelompok mahasiswa dengan kategori kecerdasan spasial rendah

A1B1 = kel. mahasiswa dengan kategori kecerdasan spasial tinggi, diajarkan dengan metode pembelajaran gambar berseri

A1B2 = kel. mahasiswa dengan kategori kecerdasan spasial rendah, diajarkan dengan metode pembelajaran gambar berseri

$\mathrm{A} 2 \mathrm{~B} 1=$ kel. mahasiswa dengan kategori kecerdasan spasial tinggi yang diajarkan dengan metode pembelajaran konvensional

A2B2 = kel. mahasiswa dengan kategori kecerdasan spasial rendah yang diajarkan dengan metode pembelajaran konvensional

\section{Prosedur Penelitian}

Adapun prosedur langkah-langkah yang akan dilakukan dalam penelitian ini terbagi menjadi tiga tahapan, yaitu :

1) Tahap Persiapan.

Kegiatan yang dilakukan pada tahap persiapan meliputi :

a. Observasi awal, dilakukan untuk mengetahui kondisi awal populasi dan sampel (kelas yang akan diuji coba). 
b. Studi literatur, dilakukan untuk memperoleh teori yang akurat mengenai permasalahan yang akan dikaji.

c. Membuat dan menyusun instrumen penelitian.

d. Menguji coba instrumen penelitian.

e. Menganalisis hasil uji coba instrumen penelitian, kemudian melakukan revisi terhadap instrumen penelitian yang kurang sesuai.

f. Menyusun Rencana Pelaksanaan Pembelajaran dengan metode gambar berseri dan konvensional.

2) Tahap Pelaksanaan.

Kegiatan yang dilakukan pada tahap pelaksanaan meliputi :

a. Memberikan tes kecerdasan spasial pada seluruh sampel dan berdasarkan hasil tes sesuai dengan tingkat kecerdasan spasial yakni kecerdasan spasial tinggi dan rendah lalu kemudian dikelompokkan pada kelas eksperimen dan kelas kontrol secara random.

b. Memberikan perlakuan (treatment) yaitu di kelas eksperimen berupa metode pembelajaran gambar berseri dan di kelas kontrol berupa metode pembelajaran konvensional. Pada saat treatment, observer mengamati keberlangsungan proses pembelajaran.

c. Memberikan tes akhir (pascates) untuk mengukur keterampilan menulis karangan deskripsi setelah diberi perlakuan sebanyak 6 kali.

d. Mengolah data hasil tes keterampilan menulis untuk mengetahui pengaruh kedua metode pembelajaran dan kecerdasan spasial terhadap keterampilan menulis karangan deskripsi mahasiswa.

3) Tahap Akhir.

Pada tahapan ini kegiatan yang akan dilakukan antara lain :

a. Memberikan kesimpulan berdasarkan hasil pengolahan data.

b. Memberikan saran berdasarkan hasil penelitian.

\section{Instrument Penelitian}

Cronbach (1990) mengklasfikasikan pengukuran ke dalam dua kelompok, yaitu maximum performance test dan typical response measure. Maximum performance test merupakan jenis tes yang digunakan untuk mengukur kemampuan individu. Peserta tes diharapkan untuk memperoleh skor sebaik mungkin yang individu dapat peroleh. Metode pengukuran yang masuk dalam kelompok ini adalah berbagai tes kecerdasan, tes bakat, dan tes prestasi. Sedangkan typical response measure merupakan jenis tes yang digunakan untuk mengukur perasaan, kebiasaan, dan kecenderungan individu. Metode pengukuran yang termasuk dalam kelompok ini adalah observasi, dan self- report yang meliputi kuisioner, angket dan inventori.

Instrumen dalam penelitian ini adalah melalui tes baik untuk mengetahui kemampuan menulis karangan deskripsi maupun untuk mengukur kecerdasan spasial

1. Instrumen Tes Kemampuan Menulis Karangan Deskripsi

2. Instrumen Tes Kecerdasan Spasial (Differential Aptitude Test) 


\section{Teknik Analisis Data}

Teknik analisis yang digunakan dalam penelitian ini adalah metode statistika non parametrik yakni uji Mann Whitney U dan Uji Kruskal Wallis H. Uji Mann Whitney digunakan untuk membuktikan hipotesis pertama dan kedua, sedangkan untuk membuktikan hipotesis ketiga digunakan Uji Kruskal Wallis H. Metode statistik nonparametrik merupakan metode statistik yang dapat digunakan dengan mengabaikan asumsi-asumsi yang melandasi penggunaan metode statistik parametrik, terutama yang berkaitan dengan distribusi normal. Statistik nonparametrik banyak digunakan pada penelitian-penelitian sosial, dimana data yang diperoleh pada umumnya berbentuk kategori atau berbentuk ranking (Tavi \& Riantri, 2010: 10).

1) Uji Mann Whitney U

Uji Mann Whitney U dikembangkan oleh Henry Mann dan Donald Ransom Whitney pada tahun 1947. Uji Mann Whitney U merupakan uji statistik nonparametrik dua kelompok sampel tidak berhubungan, dengan tujuan untuk mengetahui apakah terdapat perbedaan significant secara statistik pada data kedua sampel kelompok atau tidak. Perumusan hipotesis pengujian yaitu hipotesis nol $\left(\mathrm{H}_{0}\right)$ : kedua kelompok sampel identik (tidak terdapat perbedaan pada data kedua kelompok sampel), dan hipotesis alternative $\left(\mathrm{H}_{1}\right)$ : kedua kelompok sampel tidak identik (terdapat perbedaan pada data kedua kelompok sampel).

Data yang dianalisis pada uji Mann Whitney berupa ranking dari hasil peringkat seluruh nilai dari dua kelompok sampel. setelah sampel diberi ranking dan dijumlahkan berdasarkan kelompok sampel, kemudian menentukan nilai dari statistik uji Mann Whitney U.

2) Uji Kruskal Wallis $H$

Uji Kruskal Wallis merupakan uji statistik nonparametrik tiga atau lebih kelompok sampel.Uji kruskal Wallis identik dengan uji Anova pada statistik parametrik. Sehingga uji merupakan alternative bagi uji Anova jika tidak memenuhi asumsi normalitas. Perumusan hipotesis pengujian yaitu hipotesis nol $\left(\mathrm{H}_{0}\right)$ : tiga atau lebih kelompok sampel identik (tidak terdapat perbedaan antara kelompok sampel) dan hipotesis alternative $\left(\mathrm{H}_{1}\right)$ : tiga atau lebih kelompok sampel tidak identik (terdapat perbedaan antara kelompok sampel).

\section{Hasil Penelitian}

Hipotesis penelitian yang harus dibuktikan adalah apakah terdapat : (1) perbedaan pengaruh penggunaan metode gambar berseri dan metode konvensional terhadap keterampilan menulis karangan deskripsi mahasiswa; (2) perbedaan pengaruh kecerdasan spasial tinggi dan rendah terhadap keterampilan menulis karangan deskripsi mahasiswa; serta (3) perbedaan pengaruh kecerdasan spasial tinggi yang diajarkan dengan metode gambar berseri maupun metode konvensional dan perbedaan pengaruh kecerdasan spasial rendah yang diajarkan dengan metode gambar berseri maupun metode konvensional terhadap keterampilan menulis karangan deskripsi mahasiswa.

Tabel 2. Rangkuman Hasil Tes Menulis Karangan Deskripsi Secara Keseluruhan 


\begin{tabular}{|c|c|c|c|}
\hline $\begin{array}{l}\text { Metode } \\
\text { Pembelajaran } \\
\text { Kecerdasan } \\
\text { Spasial }\end{array}$ & Gambar Berseri & Konvensional & Total \\
\hline Tinggi & $\begin{array}{l}n_{1}=4 \\
\sum x_{1}=16 \\
\sum x_{1}^{2}=64 \\
x_{1}=4 \\
S_{1}=0\end{array}$ & $\begin{array}{l}n_{2}=5 \\
\sum x_{2}=16 \\
\sum x_{2}{ }^{2}=56 \\
\bar{x}_{2}=3,2 \\
S_{2}=1,09\end{array}$ & $\begin{array}{l}n_{b 1}=9 \\
\sum x_{b 1}=32 \\
\sum x_{b 1}{ }^{2}=120 \\
\bar{x}_{b 1}=3,55 \\
S_{b 1}=0,88\end{array}$ \\
\hline Rendah & $\begin{array}{l}n_{3}=5 \\
\sum x_{3}=19,5 \\
\sum x_{3}{ }^{2}=76,25 \\
\bar{x}_{3}=3,9 \\
S_{3}=0,22\end{array}$ & $\begin{array}{l}n_{4}=4 \\
\sum x_{4}=11 \\
\sum x_{4}^{2}=32,5 \\
\bar{x}_{4}=2,75 \\
S_{4}=0,86\end{array}$ & $\begin{array}{l}n_{b 1}=9 \\
\sum x_{b 2}=30,5 \\
\sum x_{b 2}{ }^{2}=108,75 \\
\bar{x}_{b 2}=3,38 \\
S_{b 2}=0,82\end{array}$ \\
\hline Total & $\begin{array}{l}n_{k 1}=9 \\
\sum x_{k 1}=35,5 \\
\sum x_{k 1}{ }^{2}=140,25 \\
\bar{x}_{k 1}=3,94 \\
S_{k 1}=0,16\end{array}$ & $\begin{array}{l}n_{k 2}=9 \\
\sum x_{k 2}=27 \\
\sum x_{k 2}{ }^{2}=88,5 \\
x_{k 2}=3 \\
S_{k 2}=0,97\end{array}$ & $\begin{array}{l}N=18 \\
\sum x_{b k}=62,5 \\
\sum x_{b k}{ }^{2}=228,75 \\
\bar{x}_{b k}=3,47 \\
S_{b k}=0,83\end{array}$ \\
\hline
\end{tabular}

1. Apakah terdapat perbedaan pengaruh antara penggunaaan metode pembelajaran gambar berseri dan konvensional terhadap keterampilan menulis karangan deskripsi?

Hipotesis :

$\mathrm{H}_{0}=$ kedua kelompok metode pembelajaran identik (tidak terdapat perbedaan pengaruh signifikan antara metode pembelajaran terhadap keterampilan menulis karangan deskripsi)

$\mathrm{H}_{1}=$ kedua kelompok metode pembelajaran tidak identik (terdapat perbedaan pengaruh signifikan antara metode pembelajaran terhadap keterampilan menulis karangan deskripsi)

Tabel 3. Uji Mann Whitney Keterampilan Menulis Karangan Deskripsi Antara Kelompok Metode Gambar Berseri dan Metode Konvensional

\begin{tabular}{|c|c|c|c|c|c|c|}
\hline $\begin{array}{c}\text { JR Kelompok } \\
\text { MGB }\end{array}$ & $\begin{array}{c}\text { JR Kelompok } \\
\text { MK }\end{array}$ & U1 & U2 & Nilai Kritis & $\boldsymbol{p}$-value & Ket \\
\hline 110 & 61 & 65 & 16 & 17 & 0,013 & Tolak $\mathrm{H}_{\mathbf{0}}$ \\
\hline
\end{tabular}

Keterangan :

JR = Jumlah ranking

MGB = Metode gambar berseri

MK = Metode Konvensional

U1, U2 = Nilai uji statsitik Mann Whitney 
Hasil pengujian terhadap kedua kelompok metode pembelajaran pada Tabel 3 menunjukkan bahwa nilai uji statsitik Mann Whitney $=16$, jika dibandingkan dengan nilai kritis Mann Whitney ${ }_{(0,05 ; 9,9)}=17$ maka nilai uji statsitik Mann Whitney $<$ nilai kritis Mann Whitney. Selain itu, diperoleh $p$-value $<\alpha$. Sehingga hipotesis nol $\left(\mathrm{H}_{0}\right)$ ditolak. Hal itu berarti secara keseluruhan, terdapat perbedaan pengaruh signifikan penggunaan metode pembelajaran terhadap keterampilan menulis karangan deskripsi.

Berdasarkan hasil pengujian menggunakan Uji Mann Whitney terhadap kedua kelompok tersebut dapat disimpulkan bahwa hasil menulis karangan deskripsi mahasiswa akan lebih baik jika diajarkan dengan metode gambar berseri daripada metode konvensional.

\section{Apakah terdapat perbedaan pengaruh antara kecerdasan spasial tinggi dan rendah terhadap keterampilan menulis karangan deskripsi ?}

Hipotesis :

$\mathrm{H}_{0}=$ kedua kelompok kecerdasan spasial identik (tidak terdapat perbedaan pengaruh signifikan antara tingkat kecerdasan spasial terhadap keterampilan menulis karangan deskripsi)

$\mathrm{H}_{1}=$ kedua kelompok kecerdasan spasial tidak identik (terdapat perbedaan pengaruh signifikan antara tingkat kecerdasan spasial terhadap keterampilan menulis karangan deskripsi)

Tabel 4. Uji Mann Whitney Keterampilan Menulis Karangan Deskripsi Antara Kelompok Kecerdasan Spasial Tinggi dan Rendah

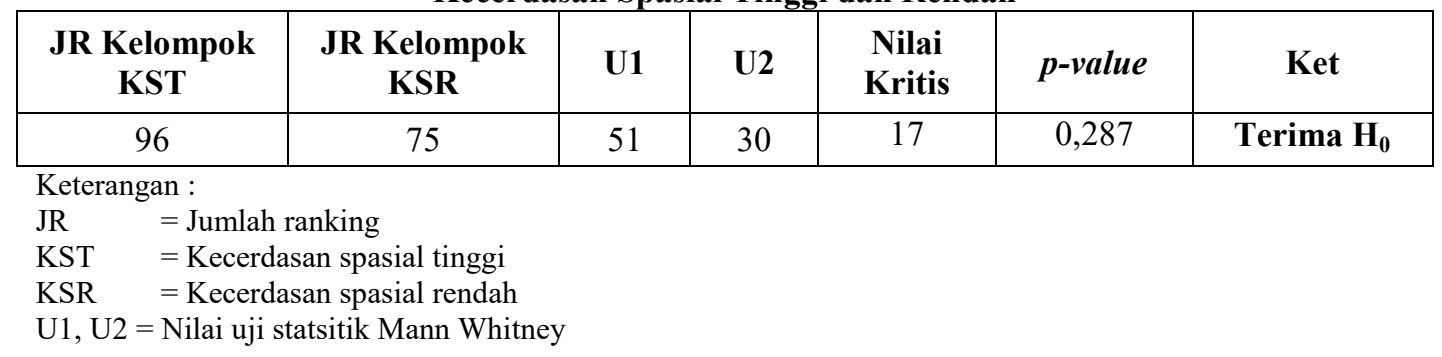

Hasil perhitungan terhadap kedua kelompok metode pembelajaran pada Tabel 4 menunjukkan bahwa nilai uji statsitik Mann Whitney $=30$, jika dibandingkan dengan nilai kritis Mann Whitney $(0,05 ; 9,9)^{=} 17$ maka nilai uji statsitik Mann Whitney > nilai kritis Mann Whitney. Selain itu, diperoleh $p$-value $>\alpha$. Sehingga hipotesis nol $\left(\mathrm{H}_{0}\right)$ diterima. Hal itu berarti secara keseluruhan, tidak terdapat perbedaan pengaruh signifikan antara tingkat kecerdasan spasial terhadap keterampilan menulis karangan deskripsi.

Berdasarkan hasil pengujian menggunakan Uji Mann Whitney terhadap kedua kelompok tersebut dapat disimpulkan bahwa hasil menulis karangan deskripsi mahasiswa pada kelompok kecerdasan spasial tinggi tidak lebih baik daripada kelompok kecerdasan spasial rendah. 
3. Apakah terdapat perbedaan pengaruh antara kecerdasan spasial tinggi yang diajarkan dengan metode gambar berseri maupun konvnsional dan kecerdasan spasial rendah yang diajarkan dengan metode gambar berseri maupun konvnsional terhadap keterampilan menulis karangan deskripsi ?

Hipotesis :

$\mathrm{H}_{0}=$ keempat kelompok sel identik (tidak terdapat perbedaan pengaruh signifikan antara keempat kelompok sel terhadap keterampilan menulis karangan deskripsi)

$\mathrm{H}_{1}=$ keempat kelompok sel tidak identik (terdapat perbedaan pengaruh signifikan antara keempat kelompok sel terhadap keterampilan menulis karangan deskripsi)

Tabel 5. Uji Kruskal Wallis Keterampilan Menulis Karangan Deskripsi Antara Keempat

\begin{tabular}{|c|c|c|c|c|c|c|c|}
\hline \multicolumn{8}{|c|}{ Kelompok Sel } \\
\hline $\begin{array}{l}\text { JR Kelompok } \\
\text { KSTMGB }\end{array}$ & $\begin{array}{c}\text { JR } \\
\text { Kelompok } \\
\text { KSTMK }\end{array}$ & $\begin{array}{c}\text { JR } \\
\text { Kelompok } \\
\text { KSRMGB }\end{array}$ & $\begin{array}{c}\text { JR } \\
\text { Kelompok } \\
\text { KSRMK } \\
\end{array}$ & $\mathbf{H}$ & $\chi_{(0,05 ; 3)}^{2}$ & p-value & Ket \\
\hline 52 & 44 & 58 & 17 & 8,5 & 7,81 & 0,037 & Tolak $\mathbf{H}_{0}$ \\
\hline $\begin{array}{l}\text { Keterangan : } \\
\text { JR } \\
\text { KSTMGB = } \\
\text { KSTMK = K } \\
\text { KSRMGB = } \\
\text { KSRMK = K } \\
\mathrm{H}\end{array}$ & $\begin{array}{l}\text { Jumlah rankin } \\
\text { ecerdasan spas } \\
\text { cerdasan spasi } \\
\text { ecerdasan spas } \\
\text { cerdasan spas } \\
\text { Nilai uji statsit }\end{array}$ & $\begin{array}{l}\text { tinggi yang di } \\
\text { tinggi yang di } \\
\text { rendah yang } \\
\text { rendah yang d } \\
\text { Kruskal Walli }\end{array}$ & $\begin{array}{l}\text { kan dengan } m \\
\text { kan dengan } m \\
\text { rkan dengan } \\
\text { rkan dengan } r\end{array}$ & $\begin{array}{l}\text { de ge } \\
\text { de ko } \\
\text { ode } q \\
\text { ode } 1\end{array}$ & $\begin{array}{l}\text { bar berseri } \\
\text { vensional } \\
\text { mbar berseri } \\
\text { nvensional }\end{array}$ & & \\
\hline
\end{tabular}

\section{Pembahasan}

Hasil perhitungan terhadap keempat kelompok sel pada Tabel 5 . menunjukkan bahwa nilai uji statsitik Kruskal Wallis $=8,5$, jika dibandingkan dengan nilai $\chi_{(0,05 ; 3)}^{2}=7,81$ maka nilai uji statsitik Mann Whitney $>$ nilai tabel $\chi^{2}$. Selain itu, diperoleh $p$-value $<\alpha$. Sehingga hipotesis nol $\left(\mathrm{H}_{0}\right)$ ditolak. Hal itu berarti secara keseluruhan, terdapat perbedaan pengaruh signifikan antara keempat kelompok sel terhadap keterampilan menulis karangan deskripsi.

Selanjutnya untuk mengetahui kelompok sel yang memberi hasil keterampilan deskripsi yang lebih baik, maka dilakukan pengujian antar kelompok sel dengan menggunakan Uji Mann Whitney U.

a) Kelompok Kecerdasan Spasial Tinggi yang diajarkan dengan metode gambar berseri dan metode konvensional

Hipotesis :

$\mathrm{H}_{0}=$ kedua kelompok sel identik (tidak terdapat perbedaan pengaruh signifikan antara kedua kelompok sel terhadap keterampilan menulis karangan deskripsi)

$\mathrm{H}_{1}=$ kedua kelompok sel tidak identik (terdapat perbedaan pengaruh signifikan antara kedua kelompok sel terhadap keterampilan menulis karangan deskripsi) 
Tabel 6. Uji Mann Whitney Keterampilan Menulis Karangan Deskripsi Antara Kelompok Sel (KSTMGB dan KSTMK)

\begin{tabular}{|c|c|c|c|c|c|c|}
\hline $\begin{array}{c}\text { JR Kelompok } \\
\text { KSTMGB }\end{array}$ & $\begin{array}{c}\text { JR Kelompok } \\
\text { KSTMK }\end{array}$ & U1 & $\mathbf{U} 2$ & Nilai Kritis & p-value & Ket \\
\hline 24 & 21 & 6 & 14 & 1 & 0,176 & Terima $\mathrm{H}_{0}$ \\
\hline $\begin{array}{l}\text { Keterangan : } \\
\text { JR } \\
\text { KSTMGB } \\
\text { KSTMK = Kecer } \\
\text { U1, U2 = Nilai }\end{array}$ & $\begin{array}{l}=\text { Jumlah ranking } \\
=\text { Kecerdasan Spasi } \\
\text { lasan Spasial Tinggi } \\
\text { ji statsitik Mann Whi }\end{array}$ & $\begin{array}{l}\text { Tinggi } \\
\text { arkan } \\
\text { V }\end{array}$ & $\begin{array}{l}\operatorname{arkan} \\
\operatorname{gan} \mathrm{N}\end{array}$ & $\begin{array}{l}\text { ngan Metode ga } \\
\text { de Konvension }\end{array}$ & bar berseri & \\
\hline
\end{tabular}

Hasil pegujian terhadap kedua kelompok sel pada Tabel 6 menunjukkan bahwa nilai uji statsitik Mann Whitney $=6$, jika dibandingkan dengan nilai kritis Mann Whitney ${ }_{(0,05 ; 4,5)}=1$ maka nilai uji statsitik Mann Whitney $>$ nilai kritis Mann Whitney. Selain itu, diperoleh $p$-value $=0,176$, jika dibandingkan dengan $\alpha$ $=0,05$ maka $p$-value $>\alpha$. Sehingga hipotesis nol $\left(\mathrm{H}_{0}\right)$ diterima. Hal itu berarti tidak terdapat perbedaan pengaruh signifikan antara kedua kelompok sel terhadap keterampilan menulis karangan deskripsi.

b) Kelompok Kecerdasan Spasial Tinggi yang diajarkan dengan metode gambar berseri dan Kelompok Kecerdasan Spasial Rendah yang diajarkan dengan metode gambar berseri

Hipotesis :

$\mathrm{H}_{0}=$ kedua kelompok sel identik (tidak terdapat perbedaan pengaruh signifikan antara kedua kelompok sel terhadap keterampilan menulis karangan deskripsi)

$\mathrm{H}_{1}=$ kedua kelompok sel tidak identik (terdapat perbedaan pengaruh signifikan antara kedua kelompok sel terhadap keterampilan menulis karangan deskripsi)

Tabel 7. Uji Mann Whitney Keterampilan Menulis Karangan Deskripsi Antara Kelompok Sel (KSTMGB dan KSRMGB)

\begin{tabular}{|c|c|c|c|c|c|c|}
\hline $\begin{array}{c}\text { JR Kelompok } \\
\text { KSTMGB }\end{array}$ & $\begin{array}{c}\text { JR Kelompok } \\
\text { KSRMGB }\end{array}$ & U1 & U2 & Nilai Kritis & p-value & Ket \\
\hline 22 & 23 & 8 & 12 & 1 & 0,371 & Terima $\mathbf{H}_{\mathbf{0}}$ \\
\hline
\end{tabular}

Keterangan :

JR = Jumlah ranking

KSTMGB $\quad=$ Kecerdasan Spasial Tinggi diajarkan dengan Metode gambar berseri

KSRMGB = Kecerdasan Spasial Rendah diajarkan dengan Metode gambar berseri

U1, U2 = Nilai uji statsitik Mann Whitney

Hasil pegujian terhadap kedua kelompok sel pada Tabel 7 menunjukkan bahwa nilai uji statsitik Mann Whitney $=8$, jika dibandingkan dengan nilai kritis Mann Whitney ${ }_{(0,05 ; 4,5)}=1$ maka nilai uji statsitik Mann Whitney $>$ nilai kritis Mann Whitney. Selain itu, diperoleh $p$-value $=0,371$, jika dibandingkan dengan $\alpha$ $=0,05$ maka $p$-value $>\alpha$. Sehingga hipotesis nol $\left(\mathrm{H}_{0}\right)$ diterima. Hal itu berarti tidak terdapat perbedaan pengaruh signifikan antara kedua kelompok sel terhadap keterampilan menulis karangan deskripsi. 
c) Kelompok Kecerdasan Spasial Tinggi yang diajarkan dengan metode gambar berseri dan Kelompok Kecerdasan Spasial Rendah yang diajarkan dengan metode konvensional

Hipotesis :

$\mathrm{H}_{0}=$ kedua kelompok sel identik (tidak terdapat perbedaan pengaruh signifikan antara kedua kelompok sel terhadap keterampilan menulis karangan deskripsi)

$\mathrm{H}_{1}=$ kedua kelompok sel tidak identik (terdapat perbedaan pengaruh signifikan antara kedua kelompok sel terhadap keterampilan menulis karangan deskripsi)

Tabel 8. Uji Mann Whitney Keterampilan Menulis Karangan Deskripsi Antara Kelompok Sel (KSTMGB dan KSRMK)

\begin{tabular}{|c|c|c|c|c|c|c|}
\hline $\begin{array}{c}\text { JR Kelompok } \\
\text { KSTMGB }\end{array}$ & $\begin{array}{l}\text { JR Kelompok } \\
\text { KSRMK }\end{array}$ & U1 & $\mathbf{U} 2$ & Nilai Kritis & p-value & Ket \\
\hline 26 & 10 & 0 & 16 & 0 & 0,013 & Tolak $\mathbf{H}_{0}$ \\
\hline \multicolumn{7}{|l|}{ Keterangan } \\
\hline JR & \multicolumn{6}{|l|}{$=$ Jumlah ranking } \\
\hline KSTMGB & \multicolumn{6}{|c|}{$=$ Kecerdasan Spasial Tinggi diajarkan dengan Metode gambar berseri } \\
\hline \multicolumn{7}{|c|}{ KSRMK = Kecerdasan Spasial Rendah diajarkan dengan Metode konvensional } \\
\hline $\mathrm{U} 1, \mathrm{U} 2$ & ji statsitik Mann Whit & & & & & \\
\hline
\end{tabular}

Hasil pegujian terhadap kedua kelompok sel pada Tabel 8. menunjukkan bahwa nilai uji statsitik Mann Whitney $=0$, jika dibandingkan dengan nilai kritis Mann Whitney $(0,05 ; 4,4)=0$ maka nilai uji statsitik Mann Whitney $=$ nilai kritis Mann Whitney. Selain itu, diperoleh $p$-value $=0,013$, jika dibandingkan dengan $\alpha$ $=0,05$ maka $p$-value $<\alpha$. Sehingga hipotesis nol $\left(\mathrm{H}_{0}\right)$ ditolak. Hal itu berarti terdapat perbedaan pengaruh signifikan antara kedua kelompok sel terhadap keterampilan menulis karangan deskripsi.

d) Kelompok Kecerdasan Spasial Tinggi yang diajarkan dengan metode konvensional dan Kelompok Kecerdasan Spasial Rendah yang diajarkan dengan metode gambar berseri

Hipotesis :

$\mathrm{H}_{0}=$ kedua kelompok sel identik (tidak terdapat perbedaan pengaruh signifikan antara kedua kelompok sel terhadap keterampilan menulis karangan deskripsi)

$\mathrm{H}_{1}=$ kedua kelompok sel tidak identik (terdapat perbedaan pengaruh signifikan antara kedua kelompok sel terhadap keterampilan menulis karangan deskripsi)

Tabel 9. Uji Mann Whitney Keterampilan Menulis Karangan Deskripsi Antara Kelompok Sel (KSTMK dan KSRMGB)

\begin{tabular}{|c|c|c|c|c|c|c|}
\hline $\begin{array}{c}\text { JR Kelompok } \\
\text { KSTMK }\end{array}$ & $\begin{array}{c}\text { JR Kelompok } \\
\text { KSRMGB }\end{array}$ & U1 & U2 & Nilai Kritis & p-value & Ket \\
\hline 24 & 31 & 16 & 9 & 2 & 0,366 & Terima $\mathbf{H}_{\mathbf{0}}$ \\
\hline
\end{tabular}

Keterangan : 
JR = Jumlah ranking

KSTMK $=$ Kecerdasan Spasial Tinggi diajarkan dengan Metode konvensional

KSRMGB = Kecerdasan Spasial Rendah diajarkan dengan Metode gambar berseri

U1, U2 = Nilai uji statsitik Mann Whitney

Hasil pegujian terhadap kedua kelompok sel pada Tabel 9 menunjukkan bahwa nilai uji statsitik Mann Whitney $=16$, jika dibandingkan dengan nilai kritis Mann Whitney ${ }_{(0,05 ; 5,5)}=2$ maka nilai uji statsitik Mann Whitney $>$ nilai kritis Mann Whitney. Selain itu, diperoleh $p$-value $=0,366$, jika dibandingkan dengan $\alpha$ $=0,05$ maka $p$-value $>\alpha$. Sehingga hipotesis nol $\left(\mathrm{H}_{0}\right)$ diterima. Hal itu berarti tidak terdapat perbedaan pengaruh signifikan antara kedua kelompok sel terhadap keterampilan menulis karangan deskripsi.

e) Kelompok Kecerdasan Spasial Tinggi yang diajarkan dengan metode konvensional dan Kelompok Kecerdasan Spasial Rendah yang diajarkan dengan metode konvensional

Hipotesis :

$\mathrm{H}_{0}=$ kedua kelompok sel identik (tidak terdapat perbedaan pengaruh signifikan antara kedua kelompok sel terhadap keterampilan menulis karangan deskripsi)

$\mathrm{H}_{1}=$ kedua kelompok sel tidak identik (terdapat perbedaan pengaruh signifikan antara kedua kelompok sel terhadap keterampilan menulis karangan deskripsi)

Tabel 10. Uji Mann Whitney Keterampilan Menulis Karangan Deskripsi Antara Kelompok Sel (KSTMK dan KSRMK)

\begin{tabular}{|c|c|c|c|c|c|c|}
\hline $\begin{array}{c}\text { JR Kelompok } \\
\text { KSTMK }\end{array}$ & $\begin{array}{c}\text { JR Kelompok } \\
\text { KSRMK }\end{array}$ & U1 & U2 & Nilai Kritis & $\boldsymbol{p}$-value & Ket \\
\hline 29 & 16 & 6 & 14 & 1 & 0,295 & Terima $\mathbf{H}_{\mathbf{0}}$ \\
\hline
\end{tabular}

Keterangan :

JR $\quad=$ Jumlah ranking

KSTMK $=$ Kecerdasan Spasial Tinggi diajarkan dengan Metode konvensional

KSRMK $=$ Kecerdasan Spasial Rendah diajarkan dengan Metode konvensional

U1, U2 = Nilai uji statsitik Mann Whitney

Hasil pegujian terhadap kedua kelompok sel pada Tabel 10 menunjukkan bahwa nilai uji statsitik Mann Whitney $=6$, jika dibandingkan dengan nilai kritis Mann Whitney ${ }_{(0,05 ; 5,4)}=1$ maka nilai uji statsitik Mann Whitney $>$ nilai kritis Mann Whitney. Selain itu, diperoleh $p$-value $=0,366$, jika dibandingkan dengan $\alpha$ $=0,05$ maka $p$-value $>\alpha$. Sehingga hipotesis nol $\left(\mathrm{H}_{0}\right)$ diterima. Hal itu berarti tidak terdapat perbedaan pengaruh signifikan antara kedua kelompok sel terhadap keterampilan menulis karangan deskripsi.

f) Kelompok Kecerdasan Spasial Rendah yang diajarkan dengan metode Gambar Berseri dan Metode konvensional

Hipotesis :

$\mathrm{H}_{0}=$ kedua kelompok sel identik (tidak terdapat perbedaan pengaruh signifikan antara kedua kelompok sel terhadap keterampilan menulis karangan deskripsi) 
$\mathrm{H}_{1}=$ kedua kelompok sel tidak identik (terdapat perbedaan pengaruh signifikan antara kedua kelompok sel terhadap keterampilan menulis karangan deskripsi)

Tabel 11. Uji Mann Whitney Keterampilan Menulis Karangan Deskripsi Antara Kelompok Sel (KSRMGB dan KSRMK)

\begin{tabular}{|c|c|c|c|c|c|c|}
\hline $\begin{array}{c}\text { JR Kelompok } \\
\text { KSRMGB }\end{array}$ & $\begin{array}{l}\text { JR Kelompok } \\
\text { KSRMK }\end{array}$ & U1 & $\mathbf{U} 2$ & Nilai Kritis & p-value & Ket \\
\hline 34 & 11 & 1 & 19 & 1 & 0,018 & Tolak $\mathrm{H}_{0}$ \\
\hline $\begin{array}{l}\text { Keterangan : } \\
\text { JR } \\
\text { KSRMGB }\end{array}$ & $\begin{array}{l}=\text { Jumlah ranking } \\
=\text { Kecerdasan Snasia }\end{array}$ & endah & rkan & gan Meto & ar herseri & \\
\hline $\begin{array}{l}\text { KSRMK }=\text { Kecer } \\
\text { U1, U2 }=\text { Nilai }\end{array}$ & $\begin{array}{l}\text { asan Spasial Rendah } \\
\text { i statsitik Mann Whit }\end{array}$ & & & de konvensiona & & \\
\hline
\end{tabular}

Hasil pengujian terhadap kedua kelompok sel pada Tabel 11 menunjukkan bahwa nilai uji statsitik Mann Whitney $=1$, jika dibandingkan dengan nilai kritis Mann Whitney $_{(0,05 ; 5,4)}=1$ maka nilai uji statsitik Mann Whitney $=$ nilai kritis Mann Whitney. Selain itu, diperoleh $p$-value $=0,018$, jika dibandingkan dengan $\alpha$ $=0,05$ maka $p$-value $<\alpha$. Sehingga hipotesis nol $\left(\mathrm{H}_{0}\right)$ ditolak. Hal itu berarti terdapat perbedaan pengaruh signifikan antara kedua kelompok sel terhadap keterampilan menulis karangan deskripsi.

Hasil pengujian hipotesis pertama menunjukan bahwa terdapat perbedaan pengaruh penggunaan metode pembelajaran terhadap keterampilan menulis karangan deskripsi. hal tersebut dapat dilihat dari hasil uji statistik Mann Whitney untuk kelompok mahasiswa yang diajarkan menggunakan metode gambar berseri dan kelompok mahasiswa yang diajarkan menggunakan metode konvensional. Berdasarkan hasil pengujian ditemukan bahwa keterampilan menulis karangan deskripsi lebih baik jika diajarkan dengan metode gambar berseri daripada metode konvensional.

Pada pengujian hipotesis kedua tidak terdapat perbedaan pengaruh tingkat kecerdasan spasial terhadap keterampilan menulis karangan deskripsi. Hasil analisis dengan uji Mann Whitney menyimpulkan bahwa tidak terdapat perbedaan pengaruh pada kelompok mahasiswa yang memiliki tingkat kecerdasan tinggi dan kelompok mahasiswa yang memiliki tingkat kecerdasan spasial rendah terhadap hasil menulis karangan deskripsi.

Sedangkan hasil pengujian hipotesis ketiga menggunakan uji Kruskal Wallis $\mathrm{H}$ menunjukan bahwa terdapat perbedaan pengaruh antara tingkat kecerdasan spasial dan penggunaan metode pembelajaran terhadap keterampilan menulis karangan deskripsi. Artinya, minimal ada satu kelompok sel yang memiliki perbedaan pengaruh terhadap keterampilan menulis karangan deskripsi.

\section{Kesimpulan}

Hal-hal yang dapat disimpulkan berdasarkan hasil penelitian adalah sebagai berikut: (1) Hasil menulis karangan deskripsi dengan menggunakan metode gambar berseri lebih baik daripada metode konvensional. (2) Hasil menulis karangan deskripsi kelompok mahasiswa dengan tingkat kecerdasan spasial tinggi tidak lebih baik dibandingkan dengan kelompok mahasiswa dengan tingkat 
kecerdasan spasial rendah. (3) Terdapat perbedaan pengaruh antara tingkat kecerdasan spasial dengan penggunaan metode pembelajaran terhadap keterampilan menulis karangan deskripsi.

\section{Daftar Rujukan}

Ahmad Rofiudin dan Darmiyati Zuhdi. 1996. Pendidikan Bahasa dan Sastra Indonesia di Kelas Tinggi. Jakarta: Depdikbud.

Alwi, Hasan. 2005.Kamus Besar Bahasa Indonesia. Jakarta : Balai Pustaka.

Azwar. 2007. Metode Penelitian. Yogyakarta: Pustaka Pelajar.

Evelyn Frey. 2010. Fit fürs Goethe Zertifikat C1 "Prüfungstraining”. Hueber Verlag, Ismaining.

Gorys Keraf. 1982. Eksposisi dan Deskripsi. Ende Flores: Nusa Dusa.

Suparno. 2007. Keterampilan Dasar Menulis. Jakarta: Depdiknas-UT.

Tizen, Ella Farida. 2008. Gambar Berseri Sebagai Media Pembelajaran. [online]. http://suaraguru.wordpress.com/2008/10/gambarberseri. html (diakses pada 17 Februari 2017)

Wagiran dan Mukh Doyin. 2005. Curah Gagasan Pengantar Penulisan Karya Ilmiah. Semarang: Rumah Indonesia.

Yusuf, Syamsu, dkk. 2012. Landasan Bimbingan dan Konseling. Bandung: PT. Remaja Rosdakarya. 